\title{
Review: Potensi Microgreens Meningkatkan Kesehatan Lansia Di Masa Pandemi COVID-19
}

\author{
Ayu Vandira Candra Kusumah dan Reni Nurjasmi \\ Program Studi Agroteknologi Fakultas Pertanian Universitas Respati Indonesia Jakarta \\ Email: ayuvandiracandra@yahoo.co.id
}

\begin{abstract}
Abstrak
Berdasarkan data COVID-19 lebih banyak menyebabkan infeksi berat dan kematian pada orang lanjut usia (lansia). Pertambahan usia akan menyebabkan tubuh mengalami berbagai penurunan akibat proses penuaan, hampir semua fungsi organ dan gerak menurun, diikuti dengan menurunnya imunitas sebagai pelindung tubuh sehingga tidak lagi kuat seperti ketika masih muda. Lansia yang memiliki penyakit penyerta seperti penyakit autoimun, diabetes, tekanan darah tinggi, kanker, jantung, dan multipatologi atau mengidap sejumlah penyakit apabila tertular COVID-19 akan mendapatkan komplikasi kesehatan yang cukup serius. Sistem imun yang sudah melemah ditambah adanya penyakit kronis dapat meningkatkan risiko COVID19 pada lansia bahkan dapat menyebabkan kematian. Salah satu upaya untuk membatasi pengaruh dari infeksi virus yaitu dengan membangun sistem imun melalui konsumsi makanan yang sehat, salah satunya adalah microgreens. Berbagai jenis tanaman telah dikembangkan sebagai microgreens antara lain jenis brassicaceae, asteraceae, apiaceae, amarillydaceae, amaranthaceae, serealia, oleaginous, cucurbitaceae, tanaman serat, tanaman aromatic serta beberapa jenis tanaman khas Indonesia. Microgreens mengandung senyawa bioaktif seperti alkaloid, antosianin, karotenoid, flavonoid, isoflavon, lignan, monoterpen, organosulfida, asam fenolat, dan saponin. Senyawa fitokimia tersebut memiliki aktivitas antioksidan yang mampu menangkal radikal bebas. Oleh karena itu, microgreens sangat potensial sebagai agen antimikroba, antihipertensi, antidiabetes, antioksidan, hepatoprotekstif, kardioprotektif, termasuk antivirus COVID-19 yang sedang mewabah saat ini. Microgreens merupakan teknologi pertanian perkotaan yang sesuai bagi lansia karena mudah dilakukan dan usia panen yang singkat akan mengurangi aktivitas fisik lansia selama perawatan. Aktivitas fisik selama budidaya. Variasi microgreens harus terus dikembangkan melalui eksplorasi berbagai jenis tanaman khas Indonensia yang potensial dikembangkan sebagai microgreens.
\end{abstract}

Kata Kunci: Pandemi COVID-19, Sistem imun, Lanjut usia, Microgreens, Pertanian perkotaan

\section{Abstract}

Based on data, COVID-19 causes more severe infections and deaths in the elderly (elderly). Increasing age will cause the body to experience various declines due to the aging process, almost all organ functions and movements decrease, followed by a decrease in immunity as body protector so that it is no longer strong as when it was young. Elderly who have comorbidities such as autoimmune diseases, diabetes, high blood pressure, cancer, heart disease, and multipathology or suffer from a number of diseases if they contract COVID-19 will get quite serious health complications. A weakened immune system coupled with chronic disease can increase the risk of COVID-19 in the elderly and even cause death. One of the efforts to limit the influence of viral infections is by building the immune system through the consumption of healthy foods, one of which is microgreens. Various types of plants have been developed as microgreens, including brassicaceae, asteraceae, apiaceae, amarillydaceae, amaranthaceae, cereals, oleaginous, cucurbitaceae, fiber plants, aromatic plants and several types of plants typical of Indonesia. Microgreens contain bioactive compounds such as alkaloids, anthocyanins,

\section{http://ejournal.urindo.ac.id/index.php/pertanian}

Article History :

Sumbitted 10 Juni 2021, Accepted 30 Juni2021, Published 30 Juni2021 
carotenoids, flavonoids, isoflavones, lignans, monoterpenes, organosulfides, phenolic acids, and saponins. These phytochemical compounds have antioxidant activity that can counteract free radicals. Therefore, microgreens are very potential as antimicrobial, antihypertensive, antidiabetic, antioxidant, hepatoprotective, cardioprotective agents, including the COVID-19 antiviral which is currently endemic. Microgreens is an urban farming technology that is suitable for the elderly because it is easy to do and the short harvest age will reduce the physical activity of the elderly during treatment. Physical activity during cultivation. Variations of microgreens must continue to be developed through exploration of various types of typical Indonesian plants that have the potential to be developed as microgreens.

Keywords: COVID-19 pandemic, Immune system, Elderly, Microgreens, Urban agriculture

\section{PENDAHULUAN}

Sudah lebih satu tahun, Indonesia berjuang melawan pandemi COVID-19 namun hingga saat ini belum ada tandatanda pandemi akan segera berakhir. Berdasarkan data selama Juni 2021 kasus orang terinfeksi COVID-19 semakin meningkat. Kota besar seperti DKI Jakarta juga tak luput dari serangan COVID-19, bahkan menjadi daerah dengan jumlah kasus tertinggi di Indonesia.

Sejauh ini, COVID-19 terlihat lebih sering menyebabkan infeksi berat dan kematian pada orang lanjut usia (lansia) dibandingkan orang dewasa atau anak-anak. Kelompok lanjut usia sering dikaitkan dengan kelompok yang rentan terhadap berbagai penyakit karena fungsi fisiologis yang berangsur-angsur akan berkurang termasuk sistem imum tubuh. Ditambah lagi, lansia juga termasuk kelompok rentan terserang penyakit- penyakit menular seperti infeksi saluran pernafasan, diare, dan pneumonia akibat menurunnya sistem kekebalan tubuh [1].
Dengan pertambahan usia, tubuh akan mengalami berbagai penurunan akibat proses penuaan, hampir semua fungsi organ dan gerak menurun, diikuti dengan menurunnya imunitas sebagai pelindung tubuh sehingga tidak lagi kuat seperti ketika masih muda. Lansia yang memiliki penyakit penyerta (komorbid) seperti penyakit autoimun, diabetes, tekanan darah tinggi, kanker, jantung, dan multipatologi atau mengidap sejumlah penyakit apabila tertular COVID-19 akan mendapatkan komplikasi kesehatan yang cukup serius [2]. Sistem imun yang sudah melemah ditambah adanya penyakit kronis dapat meningkatkan risiko COVID-19 pada lansia bahkan dapat menyebabkan kematian [1].

Hingga saat ini, COVID-19 telah menginfeksi lebih dari 100.000 penduduk dunia dan sekitar 4.000 orang di antaranya dinyatakan meninggal dunia. Kematian paling banyak terjadi pada penderita COVID19 yang berusia 80 tahun. WHO dan CDC melaporkan bahwa pada usia pra-lansia (50- 
59 tahun) angka kematian hampir 2 persen, usia 60 - 69 tahun terus naik menjadi 8 sampai 15 persen pada usia diatas 70 tahun. Kematian paling banyak terjadi pada penderita COVID-19 yang berusia 80 tahun ke atas, dengan persentase mencapai 21,9 persen [1].

Salah satu upaya untuk membatasi pengaruh dari infeksi virus yaitu dengan membangun sistem imun [3]. Sistem imun berfungsi mempertahankan tubuh dari agen asing serta memudahkan perbaikan jaringan. Bakteri maupun virus yang masuk kedalam tubuh manusia dilawan oleh sistem pertahanan kompleks dan multifaser sistem imum yang akan terus menerus memberikan perlindungan jika terjadi invasi agen asing [4]. Sistem imun dapat dipertahankan melalui kecukupan gizi terutama vitamin dan mineral serta senyawa bioaktif yang dapat ditemukan pada sayuran [5].

Kementerian Kesehatan menyarankan selama pandemi COVID-19 disarankan untuk mengonsumsi makanan yang bergizi seimbang seperti makanan yang mengandung zat gizi yang berperan aktif dalam meningkatkan daya tahan tubuh antara lain vitamin A, C, E, dan Zn yntuk meningkatkan daya tahan tubuh agar tidak tertular COVID-19 [6].

Sayuran yang memiliki kandungan senyawa bioaktif yang lebih banyak dari sayuran dewasa diantaranya yaitu microgreens [7]. Microgreens adalah tanaman muda, lunak, serta dapat dimakan setelah dipanen sebagai bibit. Tanaman kecil ini ditanam untuk tahap daun sejati pertama. Microgreens dapat dipanen pada minggu ke-1 sampai minggu ke-3 setelah perkecambahan [8]. Microgreens termasuk dalam makanan fungsional karena memiliki banyak manfaat lesehatan karena mengandung senyawa bioaktif seperti antioksidan, vitamin, flavonoid, karotenoid yang lebih tinggi dibandingkan tanaman dewasa [9].

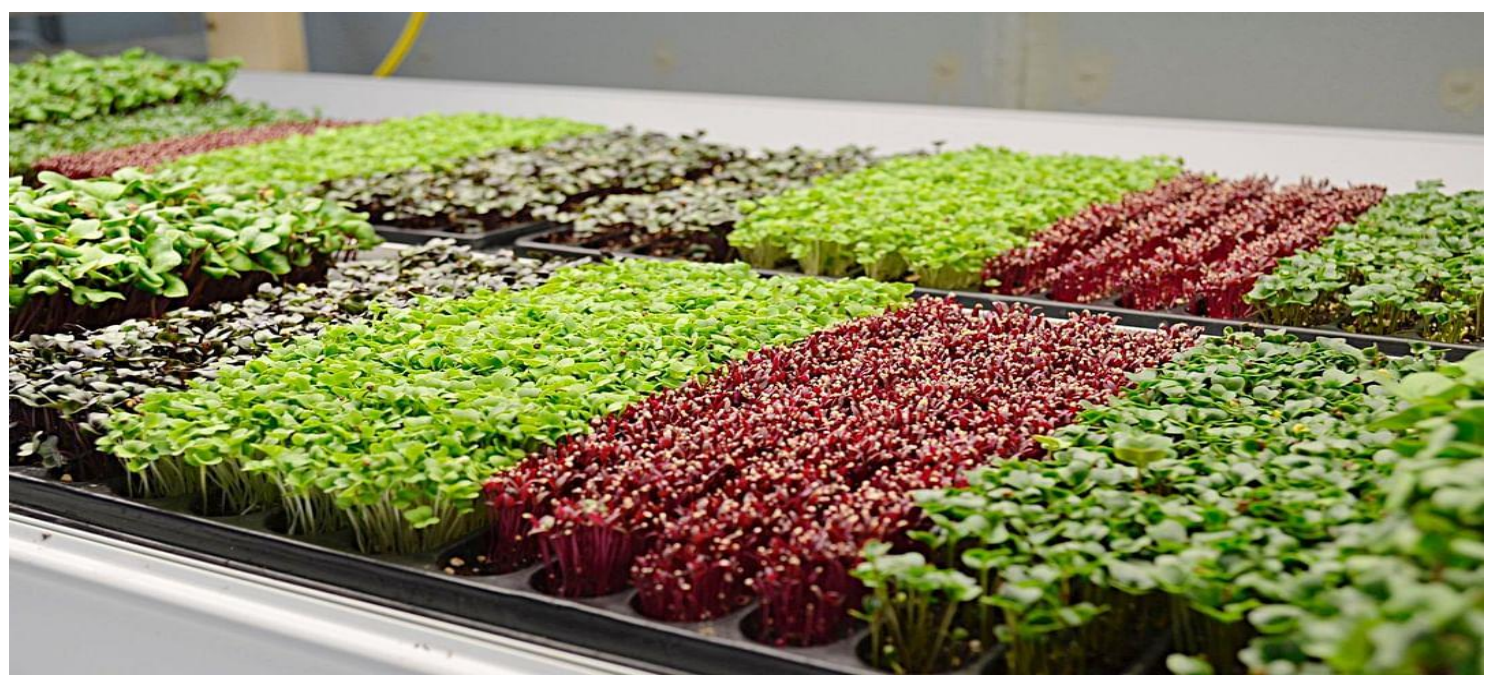


(https://www.foodtechbiz.com/agriculture/microgreens-the-modern-power-food)

Budidaya microgreens sangat cocok dilakukan oleh lansia khususunya di daerah perkotaan karena bisa dibudidayakan pada lahan sempit baik di dalam maupun luar ruangan. Usia panen yang singkat akan mengurangi aktivitas fisik lansia saat pemeliharaan microgreens. Budidaya microgreens tidak hanya menghasilkan bahan pangan yang sehat namun aktivitas fisik yang dilakukan dalam prosesnya berdampak positif bagi kesehatan lansia baik fisik maupun mental. Karantina di rumah untuk menekan penyebaran COVID-19 dapat menurunkan aktivitas fisik akibat sehingga berpotensi terjadinya penyakit tidak menular seperti jantung koroner, stroke, hipertensi, dan diabetes mellitus [10]. Menurut World Health Organization (WHO) orang yang tidak melakukan aktivitas fisik dapat menjadi salah satu penyebab terjadi kematian, data kematian tertinggi keempat secara global sebanyak $6 \%$ yaitu akibat tidak melakukan aktivitas fisik [11]. Berdasarkan hal tersebut, artikel ini bertujuan untuk mengkaji potensi microgreens untuk

meningkatkan kesehatan lansia baik fisik dan mental di masa pandemi COVID-19.

\section{METODE PENELITIAN}

Penelitian merupakan penelitian studi literatur (literature review) dengan menelaah sumber pustaka dan dokumen terkait baik berupa jurnal, buku-buku atau laporan penelitian lainnya. Hasil dari berbagai telaah sumber pustaka dan dokumen digunakan untuk mengidentifikasi potensi microgreens untuk meningkatkan kesehatan lansia baik fisik maupun mental di masa pandemi COVID-19.

\section{HASIL DAN PEMBAHASAN}

Jenis Microgreens

Microgreens secara gastronomi dan nutrisi sangat menarik karena spesies dan varietas dengan keping kotiledon serta daun pertama yang memiliki beragam bentuk, warna, tekstur dan rasa [12]. Sebanyak 80100 jenis tanaman yang telah dicoba sebagai tanaman microgreens [13]. Tabel 1 menyajikan berbagai jenis tanaman sayuran yang dapat ditanam dalam bentuk microgreens [14] dan [15]. 
Tabel 1. Jenis dan contoh tanaman yang dapat dibudidayakan dalam bentuk microgreens

\begin{tabular}{ll}
\hline \multicolumn{1}{c}{ Jenis Tanaman } & \multicolumn{1}{c}{ Contoh Tanaman } \\
\hline Brassicaceae & $\begin{array}{l}\text { Kembang Kol, Brokoli, Kubis, Kale, Selada Air, Lobak, Arugula, Mustard } \\
\text { dan Tatsoi }\end{array}$ \\
Asteraceae & Selada, Endive, Escarole, Chicory, dan Radicchio \\
Apiaceae & Wortel, Adas, dan Seledri \\
Amarillydaceae & Bawang Putih, Bawang Merah, dan Daun Bawang \\
Amaranthaceae & Bayam, Bit, Red Orach, dan Swiss Chard \\
Cucurbitaceae & Melon, Mentimun, dan Labu \\
Serealia & Wheat, Jagung, Barley, Padi, dan Sorghum \\
Quinoa & Buncis, Alfalfa, Kacang Hijau, Fenugreek, Kacang Fava, dan Miju-Miju \\
Oleaginous & Bunga Matahari \\
Tanaman Serat & Rami \\
Tanaman Aromatik & Kemangi, Basil, Daun Bawang, Daun Ketumbar dan Jintan \\
\hline
\end{tabular}

Di Indonesia, tanaman sayur dan

herbal sangat beragam sehingga potensial untuk dikembangkan sebagai microgreens dan dikenalkan kepada masyarakat agar kesadaran masyarakat terhadap makanan sehat semakin meningkat. Beberapa jenis tanaman khas Indonesia adalah kemangi (Ocimum canum), bayam merah (Alternanthera amoena), seladah merah
(Lactuca sativa var encephala), bunga kol (Brassica oleraceae var botrytis), kacang hijau (Vigna radiata), bunga matahari (Helianthus annuus), sorgum manis (Sorghum bicolor) dan kubis ungu (Brassica oleraceae) dapat dibudidayakan menjadi microgreens yang memiliki nilai gizi tinggi dibandingkan jenis microgreens impor.
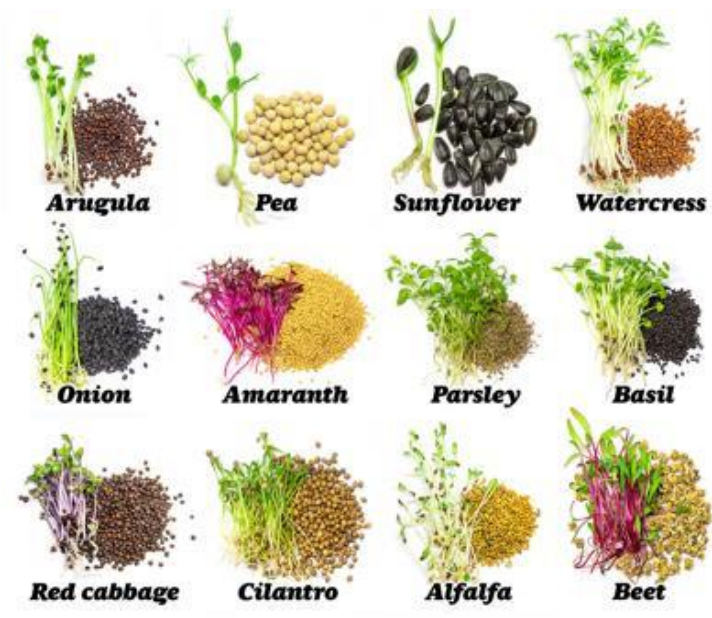

(https://feastandfield.net/read/fruits-and-vegetables/)

Senyawa Bioaktif dan Kandungan Nutrisi Microgreens
Microgreens sudah sangat populer di negara maju sejak tahun 1980 an seiring dengan meningkatnya kesadaran tentang 
hidup sehat termasuk mengonsumsi makanan sehat. Microgreens merupakan tanaman dari kelompok tanaman sayuran atau herbal yang dipanen pada umur 7-21 hari [16]. Pemanenan dapat dilakukan dengan memotong bagian batang di atas permukaan medium pertumbuhannya menggunakan gunting yang tajam. Bagian microgreens yang dikonsumsi adalah batang, kotiledon dan daun pertama yang telah membuka sempurna [17]. Microgreens mengandung senyawa bioaktif seperti pigmen, enzim, vitamin serta senyawa fitokimia lainnya 4 sampai 40 kali lebih banyak dari tanaman dewasanya karena senyawa yang ada belum digunakan untuk diferensiasi organ [18].

Kandungan vitamin C, vitamin E, vitamin $\mathrm{K}, \beta$-karoten, lutein dan zeaxanthin pada kebanyakan microgreens sepuluh kali lebih tinggi dibandingkan sayuran dewasa sejenis [19] sehingga kandungan antioksidan microgreens juga lebih tinggi. Contoh, microgreens kubis ungu bila dibandingkan dengan sayuran dewasanya mengandung rata-rata vitamin $C$ enam kali lebih tinggi (147 vs 23,5 mg / $100 \mathrm{~g}$ produk segar), vitamin E empat ratus kali lebih tinggi $(24,1$ vs $0,06 \mathrm{mg} / 100 \mathrm{~g}$ produk segar) dan kandungan vitamin $\mathrm{K}$ enam puluh kali lebih tinggi (2,4 vs $0,04 \mu \mathrm{g} / \mathrm{g}$ produk segar) [20]. Jika ditinjau tingkat asupan harian vitamin $\mathrm{C}$ (60 mg), vitamin E (13 mg) dan vitamin K (70 ug) untuk orang dewasa dengan berat badan sedang yang direkomendasikan Otoritas Keamanan Makanan Eropa (EFSA) maka dengan mengonsumsi beberapa gram microgreens saja maka sudah memenuhi kebutuhan vitamin C, vitamin $\mathrm{E}$ dan vitamin K [21].

Demikian pula dengan jenis microgreens khas Indonesia juga mengandung senyawa bioaktif seperti alkaloid, antosianin, karotenoid, flavonoid, isoflavon, lignan, monoterpen, organosulfida, asam fenolat, saponin dan lainnya [22]. Senyawa fitokimia ini memiliki aktivitas antioksidan yang mampu menangkal radikal bebas. Microgreens diharapkan dapat dijadikan sebagai agen antimikroba, antihipertensi, antidiabetes, antioksidan, hepatoprotekstif, kardioprotektif, termasuk antivirus COVID19 yang sedang mewabah saat ini.

\section{Microgreens Meningkatkan Kesehatan} Lansia

Pada abad 21, penyakit yang diderita kebanyakan lansia adalah penyakit degeneratif dan Penyakit Tidak Menular (PTM) seperti gangguan penglihatan, gangguan pendengaran, masalah gigi, nafsu makan, diabetes melitus, hipertensi, penyakit jantung, stroke, asam urat, dan kanker sedangkan penyakit menular antara lain ISPA, diare, dan pneumonia. Lansia juga rentan menderita gangguan kesehatan jiwa seperti depresi, demensia, gangguan cemas, dan sulit tidur. Penyakit tersebut akan 
menimbulkan permasalahan jika tidak diatasi atau tidak dilakukan pencegahan, karena dapat menjadi penyakit yang bersifat kronis dan multi patologis.

Lansia dengan penyakit bawaan tersebut dapat berisiko kematian jika terpapar COVID-19. Tidak jarang penyakit kambuh karena gaya hidup tidak sehat lansia selama masa pandemi. Pemicunya adalah kurang aktivitas fisik dan sering mengonsumsi makanan siap saji. Salah satu upaya untuk mencegah maupun menurunkan resiko penyakit pada lansia dapat dilakukan dengan meningkatkan asupan makanan yang bergizi, salah satunya microgreens. Jumlah vitamin, mineral, dan senyawa tanaman bermanfaat tinggi dalam microgreens, sehingga dapat mencegah maupun menurunkan bahaya berbagai penyakit [23].

Microgreens mengandung antioksidan seperti polifenol yang mampu mengurangi risiko penyakit jantung karena microgreens dapat menurunkan level trigliserida dan kolesterol LDL "jahat" [24]. Microgreens dapat memodulasi penambahan berat badan dan metabolisme kolesterol serta dapat melindungi terhadap penyakit kardiovaskular dengan mencegah hiperkolesterolemia. Polifenol juga mampu menurunkan kemungkinan penyakit terkait memori seperti alzheimer [25] dan risiko terkena diabetes tipe 2 [26], serta mengurangi bahaya berbagai jenis kanker [27].

Microgreens juga mengandung betakaroten yang lebih tinggi dibandingkan wortel. Sayuran super bergizi ini juga menyediakan karotenoid seperti lutein dan zeaxanthin yang memiliki peran penting sebagai nutrisi mata penting yang berperan mengurangi risiko degenerasi makula dan katarak. Kelompok cruciferous seperti brokoli dan kubis merupakan prebiotik yang terbukti meningkatkan ketahanan alami tubuh terhadap serangan patogen.

Kegiatan berkebun seperti budidaya microgreens memiliki efek terapeutik pada kesehatan mental. Berkonsentrasi saat merawat tanaman, menabur benih, menyiram dapat mengalihkan pikiran kita dari stres dan menimbulkan efek menenangkan. Kegiatan berkebun dalam ruangan seperti microgreens dapat mengurangi gejala fisik stres seperti tekanan darah tinggi dan membantu merasa lebih damai dengan diri mereka sendiri.

Bakteri yang ditemukan di tanah yaitu Mycobacterium vaccae dapat menginduksi produksi serotonin yaitu zat kimia bahagia di otak yang membantu perasaan sehat. Microgreens kemangi, kacang polong, peterseli, bayam, pak choi merah, kubis, bayam, selada, dan kangkung bisa menjadi pilihan yang baik untuk berkebun di dalam ruangan karena tumbuh dengan cepat sehingga memudahkan pemeliharaan serta 
dapat memberikan perasaan yang memuaskan bagi otak. Tanaman yang berwarna hijau bisa membuat pikiran menjadi lebih segar. Warna-warni tanaman bisa meningkatkan kadar kebahagiaan orang hingga 30 sampai 40 persen.

\section{KESIMPULAN}

Microgreens berpotensi sebagai makanan yang menyehatkan bagi lansia terutama di masa pandemic COVID-19 karena mengandung berbagai nutrisi dan senyawa bioaktif yang terbukti mampu meningkatkan sistem imun sehingga dapat menurunkan maupun mencegah berbagai penyakit. Microgreens sangat cocok dibudidayakan oleh lansia karena mudah dilakukan serta usia panen yang singkat akan mengurangi aktivitas fisik lansia. Kegiatan menanam, merawat, dan memanen selama budidaya microgreens juga memberi dampak positif bagi kesehatan mental. Untuk menambah variatif jenis microgreens yang dapat dibudidayakan di Indonesia maka perlu dilakukan eksplorasi jenis tanaman yang potensial dan khas Indonesia sebagai microgreens.

\section{DAFTAR PUSTAKA}

Aswani, T. 2020. Hindari Lansia dari COVID19.

http://www.padk.kemkes.go.id/article/ $\mathrm{read} / 2020 / 04 / 23 / 21 /$ hindari-lansiadari-covid-19.html.
Ika. 2020. Pakar UGM Paparkan Penyebab Lansia Rentan Terinfeksi Covid. https://www.ugm.ac.id/id/berita/1932 0-pakar-ugm-paparkan-penyebablansia-rentan-terinfeksi-covid.

Susilo, A., Rumende, C. M., Pitoyo, C. W., Santoso, W. D., Yulianti, M. Herikurniawan, Yunihastuti, E. 2020 Coronavirus Disease 2019: Tinjauan Literatur Terkini. Jurnal Penyakit Dalam Indonesia, 7(1): 45-67.

Sherwood, L. 2002. Fisiologi Manusia: dari Sel ke Sistem. EGC. Jakarta.

Siswanto, B., \& Ernawati, F. 2013. Peran Beberapa Zat Gizi Mikro dalam Imunitas. Gizi Indon, 36(1): 57-64.

Kementerian Kesehatan RI. 2020. Pedoman Pencegahan dan Pengendalian Coronavirus Disease Covid-19. Direktorat Jenderal Pencegahan dan Pengendalian Penyakit. Jakarta.

Widiwurjani, G., \& Andasari, P. 2019. Status Kandungan Sulforaphane Microgreens Tanaman Brokoli (Brassica oleracea L.) pada Berbagai Media Tanam dengan pemberian Air Kelapa sebagai Nutrisi. Jurnal IImiah Hijau Cendikia, 4(1): 3438.

Kaiser, C., \& Ernst, M. 2018. Microgreens. CCD-CP-104. Lexington, KY: Center for Crop Diversification. 1-3.

Brazaityte, A., Virsile, A., Jankauskiene, J., Sakalauskiene, S., Samuoliene, G., Sirtautas, R., . . Duchovskis, P. 2015. 
Effect of Supplemental UV-A Irradiation in Solid-State Lighting on The Growth and Phytochemical Content of Microgreens. International Agrophys, 29: 13-22.

Chen, P., Mao, L., Nassis, G. P., Harmer P., Ainsworth, B. E., Li, F. 2020. Coronavirus disease (COVID-19) : The Need to Maintain Regular Physical Activity While Taking Precautions. Journal of Sport and Health Science 9: 103-104.

World Health Organization. 2017. "a Guide for Population Based Ap- proaches to Increasing Levels of Physical Activi- ty : Implementation of the WHO Strategy on Diet, Physical Activity and Health": 24. "Physical activity". <https://www.who.int/dietphysicalacti vity/pa/en/>.

Renna, M., Castellino, M., Leoni, B., Paradiso, V. M., \& Santamaria, P. 2016. Microgreens Production with Low Potassium Content for Patients with Impaired Kidney Function. Nutriens, 10(6), E675.

Treadwell DD, Hochmuth R, Landrum L, Laughlin W. 2010. Microgreens: A New Specialty Crop. Horticultural Sciences Department, Florida Cooperative Extension Service, Institute of Food and Agricultural Sciences, University of Florida.
Khyade, V. B., \& Jagtap, S. G. 2016. Sprouting Exert Significant Influence on the Antioxidant Activity in Selected Pulses (Black Gram, Cowpea, Desi Chickpea and Yellow Mustard). World Scientific News, 73-86.

Schramm, D. D. 2018. Revitalizing Human Health can be Achieved through Herbal Microgreen Permaculture. Florida: Crimson Publisher.

Delian, E., Chira, A., Badulescu, L., \& Chira, L. 2015. Insights Into Microgreens Physiology. Scientific Papers. Series B, Horticulture, LIX.

Lobiuc, A., Vasilache, V., Pintilie, O., Stoleru, T., Burducea, M., Oroian, M., \& Zamfirache, M.-M. 2017. Blue and Red LED Illumination Improves Growth and Bioactive Compounds Contents in Acyanic and Cyanic Ocimum basilicum L. Microgreens. Molecules, 22(12): 2111.

Samuolien, G., Brazaitytè, A., Viršilè, A., Jankauskienè, J., Sakalauskienè, S., \& Duchovskis, P. 2016. Red Light-Dose or Wavelength-Dependent Photoresponse of Antioxidants in Herb Microgreens. Plos One, 0163405.

Bhatt, P., \& Sharma, S. 2018. Microgreens: A Nutrient Rich Crop that Can Diversify Food System. Int Journal App Bioscience, 6 (2): 182-186.

Xiao, Z., Lester, G. E., Luo, Y., \& Wang, Q. 2012. Assesment of Vitamin and 
Carotenoid Concentrations of Emerging Food Product: Edible Microgreens. Journal of Agricultural and Food Chemistry, 60: 7644-7651.

Weber, C. F. 2017. Broccoli Microgreens: A Mineral-Rich Crop That Can Diversify Food Systems. Frontier in Nutrition. doi: https://doi.org/10.3389/fnut.2017.000 07.

Nurbayanti. 2017. Uji Senyawa Bioaktif dari Tujuh Spesies Ekstrak Metanol Microgreen Broad Leaf sebagai Antikanker. Bandung: Skripsi, UIN Sunan Gunung Djati.

Carter, P., Gray, L. J., Troughton, J., Khunti, K. and Davies, M. J. 2010. Fruit and Vegetable Intake and Incidence of Type 2 Diabetes Mellitus: Systematic Review And Meta-Analysis. BMJ (Online), 341(7772): 543. https://doi.org/10.1136/bmj.c4229.

Huang, H., Jiang, X., Xiao, Z., Yu, L., Pham, Q., Sun, J., Chen, P., Yokoyama, W., Yu, L. L., Luo, Y. S. and Wang, T. T. Y. 2016. Red Cabbage Microgreens Lower Circulating Low-Density Lipoprotein (LDL), Liver Cholesterol, and Inflammatory Cytokines in Mice Fed a High-Fat Diet. Journal of Agricultural and Food Chemistry, 64(48): 91619171.
https://doi.org/10.1021/acs.jafc.6b03805Ky riacou.

Guest, J. and Grant, R. 2016. The Benefits of Natural Products for Neurodegenerative Diseases. Advances in Neurobiology, 12: 199-228. https://doi.org/10.1007/978-3-31928383-8.

Wadhawan, S., Tripathi, J. and Gautam, S. 2018. In Vitro Regulation of Enzymatic Release of Glucose and Its Uptake by Fenugreek Microgreen and Mint Leaf Extract. International Journal of Food Science and Technology, 53(2): 320326.

https://doi.org/10.1111/ijfs.13588.

Zhou, Y., Zheng, J., Li, Y., Xu, D. P., Li, S., Chen, Y. M. and Li, H. Bin. 2016. Natural Polyphenols for Prevention and Treatment of Cancer. Nutrients, 8(8). https://doi.org/10.3390/nu8080515. 